\title{
O staropolskim opolu, śląskim weichbildzie i szlacheckim powiecie*
}

\section{Vom altpolnischen Opole (Gegenote), schlesischen Weichbild und Powiat des Adels}

1. Wprowadzenie. 2. Opole staropolskie. 2.1. Graniczenie. 2.2. Potwierdzanie prawa własności. 2.3. Gegenote w Rękopisie Elbląskim. 2.4. Bos et vacca. 2.5. Miód opolny. 2.6. Zwolnienie od opola. 3. Sląski weichbild. 4. Powiat szlachecki.

1. Einleitung. 2. Altpolnische Opole. 2.1. Grenzgang. 2.2. Der rechte Eigentümer. 2.3. Gegenote in der Elbinger Handschrift. 2.4. Ochs und Kuh. 2.5. Opole-Honig. 2.6. Befreiung vom opole. 3. Weichbild. 4. Powiat des Adels.

1. Tak zwany Geograf Bawarski z 9. w. ${ }^{1}$ przekazuje najstarszy w Polsce ślad opola na Górnym Śląsku we wzmiance: Opolini $X X$ civitates. Nazwę tego plemienia wywodzi się zazwyczaj od polożonego nad Odrą Opola. $\mathrm{Na}$ ogól jednak ówczesne nazwy plemienne Słowian nie pochodzą od grodów lub miast. Dlatego nie wykluczam jako alternatywy, iż opolami nazywano wtedy liczne polany w puszczy leżącej na wschód od Odry. One mogłyby również dać nazwę temu plemieniu. Do opola takiego dawnego typu zaliczyć trzeba ewentualnie także niektóre $\mathrm{z}$ miejscowości, wymienionych pod tą nazwą w Slowniku geograficznym ziem polskich.

* Przedstawiane tu studium stanowi skróconą wersje mojej rozprawy Vom altpolnischen Opole, schlesichen Weichbild und Powiat des Adels, ZFO 1993, Bd. 42, H. 2, s. 161-194. Zastosowane w przypisach skróty: CDB - Codex diplomaticus et epistolaris regni Bohemiae; KDKK - Kodeks dyplomatyczny katedry krakowskiej; KDM - Kodeks dyplomatyczny Malopolski; KDP - Codex diplomaticus Poloniae; KDS - Kodeks dyplomatyczny Ślqska; KDW - Kodeks dyplomatyczny Wielkopolski; KHKM - „Kwartalnik Historii Kultury Materialnej”; LBD - Liber beneficiorum diocesis Cracoviensis (Jana Dlugosza); MPH - Monumenta Poloniae Historica; NZPP -- Najstarszy Zwód Prawa Polskiego; PH - „Przegląd Historyczny”, PiM

- O. Kossmann, Polen im Mittelalter, I, II; PrUb - Preußisches Urkundenbuch; SH - „Studia Historyczne”; SUb - Schlesisches Urkundenbuch; UDK - Dokumenty kujawskie i mazowieckie; ZDM - Zbiór dokumentów malopolskich; ZfO - „Zeitschrift für Ostforschung”.

${ }^{1}$ PiM II, s. 6 i $n$. 
Na lewym brzegu Odry, naprzeciw wyżej wspomnianych polan, rozciągały się bezleśne tereny lessu, gleby stepowej, z którymi „Bawarczyk” wiąże inne plemiona górnośląskie. Po wcieleniu ich do rozrastającego się młodego państwa polskiego wszystkie te terytoria wraz ze swą strukturą administracyjną zniknęły w ówczesnych kasztelaniach. Nazwa Opole zachowała się jedynie dla stolicy księstwa, podczas gdy w lasach południowej Rosji, rozciągającej się również wzdłuż terenów lessowych, podobne - choć kilkakrotnie większe - polany zachowaly swoją dawną nazwę opolje ${ }^{2}$. Encyklopedie polskie notuja prawdopodobnie tego samego typu opola na Ukrainie zachodniej ${ }^{3}$. Różnią się one swym stałym geograficznym terenem od zmiennych terytorialnie chyba nieco późniejszych staropolskich opoli, które opisuje dokładnie J. S. Matuszewski.

2. Autor pierwszej książki o polskim opolu - J. S. Matuszewski ${ }^{4}$ - dyskutuje wnikliwie $\mathrm{z}$ autorami rozpraw na ten temat ( $\mathrm{K}$. Buczek, H. Lowmiański, Z. Podwińska, T. Lalik, K. Modzelewski itd.) $)^{5}$. W 1937 r. również i ja przedstawiłem polskie opole $\mathrm{m}$. in. jako zmienne terytorium ${ }^{6}$, w sposób zbliżony do ujęcia $\mathrm{w}$ teorii Matuszewskiego, który rozwinął ją $\mathrm{z}$ wręcz genialną logiką na wielką skalę.

2.1. O udziale circumsedentium lub circummanentium $w$ postępowaniu związanym $\mathrm{z}$ ustalaniem granic posiadłości ziemskich $\mathrm{w}$ Polsce najwcześniej informują dokumenty śląskie. Circumsedentes dosłownie odpowiada ummesessen w Zwierciadle Saskim, a owe dokumenty nazywają ich odpowiednio po polsku „osadą". Już pod koniec 12. w. - jak wynika z dokumentu Henryka Brodatego z 1208 r. - „osada" obchodziła granice?.

Podrobiony na przelomie 13/14 stulecia falsyfikat dokumentu tegoż księcia datowany na rok $1202^{8}$, stawia zamiast cum circumsedentibus termin vicinia, zamiast populares stawia vulgus. Henryk III $\mathrm{w}$ dokumencie $\mathrm{z}$ roku

${ }^{2}$ Bolszaja sowietskaja encyklopiedija, t. 18, wyd. 3, Moskwa 1974, s. 430.

${ }^{3}$ Encyklopedia powszechna, t. 19, Warszawa 1865, s. 972; Slownik geograficzny ziem polskich, t. 7, Warszawa 1886, s. $560 \mathrm{i}$ n.

4 J. S. M a t u s zew ski, Vicinia id est... Poszukiwania alternatywnej koncepcji staropolskiego opola, Lódź 1991, s. 235.

5 K. Buczek, Organizacja opolna w Polsce średniowiecznej, SH 1970, 13, s. 205-250; H. Lowmiański, Poczqlki Polski, t. 3, Warszawa 1967, s. 372-404; t. 4, Warszawa 1970, s. 46-73; Z. Pod wińs k a, Zmiany form osadnictwa wiejskiego na ziemiach polskich, Wrocław 1971, s. 288; T. Lalik, Organizacje sqsiedzkie średniowiecznej wsi polskiej - wies, opole, parafia, KHKM 1976, t. 24, s. 443 i n.; K. Modzelewski, Organizacja opolna w Polsce piastowskiej, PH 1986, t. 77, s. 177-222; PiM II, s. 217-230.

${ }^{6}$ O. Kossmann, Die deutschrechtliche Siedlung in Polen, Leipzig 1937, s. 121; PiM II, s. $219 \mathrm{i} \mathrm{n}$.

${ }^{7}$ KDS II, 22, 43, r. 1208, oraz 188, r. 1218; KDKK I, 20, r. 1224.

KDS I, 324 i 224. 
1205 mówi wyraźnie o uczestnictwie vicinia assistente przy ochodzy granic ${ }^{9}$. Ale byla też mowa o poświadczeniu populi circum sedentis oraz populorum vicinorum lub o universitas vicinie ${ }^{10}$, przy czym słówko circum najlepiej umiejscawia ten "ogół sąsiedztwa".

Circuitio taka albo obchód graniczny odbywały się zapewne zwykle przez objazd konny (circum equitatio, ujazd - często poświadczony nazwami miejscowości). Jednocześnie chłopi $\mathrm{z}$,osady" (= ummesessen) oznaczali granice za pomocą rowów, wałów, pali lub słupów, kamieni z napisem lub znakiem $^{11}$, przez „ciosny" 12 i przesieki.

W Polsce centralnej ten proces rozgraniczania rozpocząl się $\mathrm{z}$ pewnym opóźnieniem. W okręgu łódzkim odbył się na wielką skalę - evocata vicinia - dopiero w 1285 r. Dotyczył wtedy posiadłości biskupa włocławskiego, rozsianych na terenie dawnej kasztelanii wolborskiej ${ }^{13}$.

Terminy vicinia lub „opole" w dokumentach wielkopolskich spotykamy czéściej dopiero w drugiej połowie 13. w. przy nadaniu prawa niemieckiego, związanego ze zwolnieniem od ciężarów prawa polskiego ${ }^{14}$. Mowa jest tam $\mathrm{m}$. in. a vicinia, quod opole wlgariter appellatur, albo zwykle krótko: ab opole, a to przeszło 50 razy, głównie $w$ dokumentach $\mathrm{z}$ trzech ostatnich dziesięcioleci 13 . w. ${ }^{15}$

W niektórych dokumentach czytamy wyraźniej: ...ab opole, id est vicinia aliarum villarum eisdem (wsiom wspominanym uprzednio) conterminalium ${ }^{16}$ albo: ...ab opole, cum eo in nullo penitus stare ${ }^{17}$, gdzie już nie mówi się o granicach spornych ani wsiach sąsiednich, lecz o ich mieszkańcach. To samo dotyczy wzmianki $\mathrm{z}$ roku 1284: Nec unquam stabunt in opolie cum aliis villis, nec citati aliquem in opolie mittere tenebuntur ${ }^{18}$.

Pozywanie to odbywało się przez - dwukrotnie wspomniana w źródlach - laskę opolną, puszczaną $w$ obieg od chaty do chaty ${ }^{19}$, jak to pamiętam $\mathrm{z}$ własnego doświadczenia $\mathrm{z}$ podłódzkich wsi okresu międzywojennego, gdy soltys zwolywal swoich chłopów. Laski używali chyba

${ }^{9}$ SUb III, 91; podobnie w r. 1260, SUb III, 209.

${ }^{10}$ SUb III, 231, r. 1261.

11 KDS II, 49, r. 1208.

${ }_{12} \mathrm{KDP}$ II $/ 2,579$, r. 1488; incisiones antiquas alias Cziossnij.

$13 \mathrm{KDP}$ II $/ 1,126$.

14 Starsze wzmianki często $w$ falsyfikatach, np. KDW I, 40, r. 1143; albo z lat 1145, 1181, 1186 dla klasztoru lądzkiego; z r. 1209 dla klasztoru w Kaliszu.

15 Por. wykres Chronologia wielkopolskich przywilejów prawa niemieckiego 1200-1400, s. 16.

${ }^{16} \mathrm{KDM}$ I, 123, r. 1284; KDM II 155 i n., r. 1284; KDW II, 12, r. 1288; KDW II, 81, r. 1293.

${ }^{17} \mathrm{KDW}$ I 505 i 508, r. 1284; KDW VI, 39, r. 1283.

18 KDM I 126.

19 KDW II, 58, r. 1292; KDW II, 12, r. 1288. 
również średniowieczni sędziowie, gdy pozywali kogoś do sądu „za pomocą znaku sędziego"20.

Niewątpliwie również dokumenty z centralnej Polski, w których mowa o opolu, dotyczą - jak dowiódł J. S. Matuszewski - przede wszystkim regulacji granic. Prowadzą nas czasem aż do wschodnich kresów ówczesnej Polski, np. do Ukraińców kolo Przemyśla, gdzie dobrzy starcy, jako zastępcy opola, obradują między sobą i wskazują przebieg granicy. Według ich zeznań, objeżdżają granicę starostowie, bojarzy, obywatele i wielu dobrych ludzi ${ }^{21}$. Najwidoczniej posiadłości w centralnej i wschodniej Polsce $w$ połowie 14 . w. nie były jeszcze wszędzie dokładnie rozgraniczone, podczas gdy Śląsk i pod tym względem wyprzedzał inne prowincje.

2.2. Według nieco późniejszych dokumentów rola vicinii nie była jednak ograniczona wyłącznie do regulacji granic. Czasem musiała ona poświadczać, kto jest właścicielem spornego gruntu. I tak $\mathrm{np}$. gdy w roku 1295 comes Thomislaus rościl sobie prawo do dwóch sortes Postcowo et Ruscowo wsi Przybysław biskupa lubuskiego ${ }^{22}$, zwolana vicinia zeznała, że te dwie sortes należą do wsi Przybysław. Dokument dosłownie nigdzie nie wspomina o sporze granicznym.

Również w dokumencie sprzedaży Dzierżkówka dokonanej ok. $1228 \mathrm{r}$. coram vicinis circumiacentibus względnie coram eadem vicinia nie ma żadnej wzmianki o granicach ${ }^{23}$. W dokumencie z 1341 r. (!), w którym król zrzeka się pewnych pól we wsi Przebieczany, mowa jest wyłącznie o legalnym właścicielu, przy czym vicinia potwierdza, że pola te należą do biskupa lubuskiego już od przeszło 100 lat. $O$ granicach ani słowa! ${ }^{24}$ Podobnie książę Ziemowit w roku 1377 (!) zwraca wieś Gzdów plebanowi Mszczonowa, ponieważ seniores viciniae poinformowali go o prawdzie $w$ tej sprawie ${ }^{25}$. O poświadczeniu granic przez starców zupełna cisza. Sprawą gzdowską było jedynie ustalenie właściciela.

Według Zwierciadła Saskiego również ummessessen (circumsedentes) występowali jako świadkowie podczas sporów o prawo posiadania ${ }^{26}$. Poświadczenie prawa własności przez viciniam (sąsiedztwo) przewidziane bylo także w postanowieniach pruskich $\mathrm{z}$ lat $1233 \mathrm{i} 1251 \mathrm{w}$ art. 8 pod tytułem: De impeticione possessionis ${ }^{27}$.

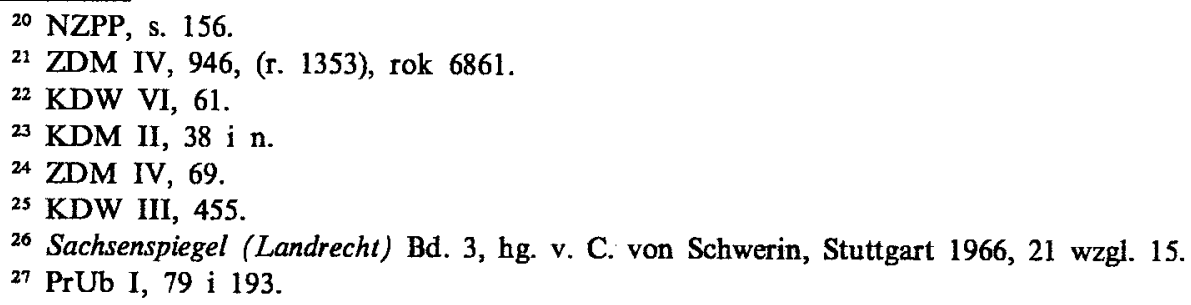


Vicinia podlegała karom za fałszywe zeznania. Również kary pieniężne były przewidziane $\mathrm{w}$ wypadku, gdy vicinia została skazana na communi solutione capitis lub $w$ innych sprawach ${ }^{28}$. Zatem poświadczeniowa rola opola - co najmniej od połowy 13. w. - nie ograniczała się jedynie do wskazania granic. Dokument z 1277 r. dla klasztoru w Lubiniu wymienia niektóre z tych dodatkowych zadań:

1) septuaginta (znana wysoka kara pieniężna);

2) bos et vacca (coroczna danina opolna);

3) homicidia ${ }^{29}$.

$\mathrm{Z}$ tego także wynika, że opole wówczas już występowało jako stałe terytorium.

2.3. Rękopis Elbląski (czyli Najstarszy Zwód Prawa Polskiego), pochodzący według moich badań $\mathrm{z}$ lat siedemdziesiątych $13 . \mathrm{w}^{30}{ }^{30}$, niestety nie wspomina nigdzie literalnie o „opolu" albo „sąsiedztwie" (vicinia). Przyjmuje sie wszakże od dawna, że zabytek używa terminu gegenote zamiast „opole”. Gegend w dzisiejszym języku niemieckim oznacza okolicę nie ograniczoną. Według slownika J. i W. Grimm około roku 1100 używano tego terminu $\mathrm{w}$ sensie terytorium, a jeszcze w 15 . w. słowo municipium było thumaczone jako creis vel lant vel gegenote ${ }^{31}$. Można by nawet podejrzewać, że już ówczesne prawo polskie używało zamiast „opole" slowa "okolica", które autor Rękopisu Elbląskiego thumaczył automatycznie słowem „gegenote". "Okolica" odpowiada literalnie niemieckiemu Umkreis. Oba mogły być synonimem dla „opola", tj. terytorium circum sedentium lub ummesessen bądź villarum conterminalium.

Gegenote, 9 razy wymieniona w Rękopisie Elbląskim, na pierwszy rzut oka raczej wygląda na terytorium ograniczone. Nadal pozostaje jednak pytanie, czy to terytorium ograniczone trwale, czy też doraźnie, np. zależnie od miejsca zbrodni? (Zastanawia przy tym, że slowo gemerke, które dawniej w języku niemieckim było używane w sensie 'granica'32, występuje tylko raz jeden w Rękopisie, gdy byla mowa o granicy ziemi!) ${ }^{33}$.

Ta niepewność pozostaje, gdy mowa o zapłacie za pozwanie do sądu mieszkańca $z$ innej wsi lub gegenote albo o wilkierzach (przepisach) w niektórych gegenote, albo o sprowadzeniu złoczyńcy z jednej gegenote do drugiej $j^{34}$.

${ }^{28}$ SUb III, 231, r. 1261; SUb II, 238, r. 1249; si aliquando ad aliquas metas vel terminos faciendas vel ob aliud quodlibet negocium vicinia fuerit evocata, et ipsam in aliquo contigerit condempnari...

${ }^{29} \mathrm{KDW}$ I, 410; KDW I, 363; KDW I, 119.

30 PiM I, 304.

31 J. i W. Grimm, Deutsches Wörterbuch, Bd. IV/1, Lipsk 1897, s. 2228.

32 Słowo Grenze dopiero wtedy przejęto $\mathrm{z}$ języka polskiego.

33 NZPP XI/4, s. 175.

34 NZPP, s. 154,154 i n., 174,178 i n. 
Termin gegenote występuje nadto w Rękopisie Elbląskim kilkakrotnie przy opisie dochodzenia sądowego według staropolskiego prawa, które rozróżnia dwa sposoby postępowania w zależności od miejsca popełnienia zabójstwa:

1) na polu albo na drodze i nie wiadomo, kto go zabili35;

2) we wsi lub $w$ pobliżu wsi ${ }^{36}$.

Przy postępowaniu w pierwszym przypadku sędzia albo książę zwolywali całą gegenote. Gdy ta nie mogła wskazać zabójcy, musiała płacić główszczyznę. Mam dokumenty stwierdzające tego rodzaju wyroki. Na przykład śląski dokument $\mathrm{z} 1261 \mathrm{r}$. powiada: ...si universitas viciniae condempta fuerit vel in communi solutione capitis..., a akt z $1253 \mathrm{r}$. ....si solucio capitis super viciniam ceciderit ${ }^{37}$. Dzięki temu możemy stwierdzić, że gegenote Rękopisu rzeczywiście stanowić winna odpowiednik terminu vicinia!

Gegenote mogła wprawdzie wedhug Rękopisu Elbląskiego także obwinić jakaśs wieś, jeśli miała po temu powód. Wieś z kolei mogła uwolnić się od kary, gdy wskazała ród, że przezeń zabójstwo zostalo dokonane, a ród móg1 winę zarzucić jakiemuś mężczyźnie. Obwinieni mogli oczyścić się od podejrzenia, odwołując się do sądu bożego ${ }^{38}$. To całe postępowanie gegenote uderzająco przypomina stosunki angielskie ok. $1000 \mathrm{r}$., gdzie rolę opola pełniła centena, a role wsi - decima ${ }^{39}$.

Odmiennie - według Rękopisu Elbląskiego - postępowano w razie zabójstwa dokonanego we wsi albo w jej poblizu, co nie mogło pozostać nie zauważone przez chłopów. Gdy chlopi nie moga schwytać zabójcy albo złodzieja, muszą gonić go z krzykiem do następnej wsi. Ta wieś przejmuje pościg, kontynuowany bez przerwy od wsi do wsi, od gegenote do gegenote ${ }^{40}$, która - jak $z$ tego wynika - nie była terytorium większym. Taka pogoń za złoczyńcą była obca niemieckiemu prawu ${ }^{41}$.

Niestety nawet $\mathrm{z}$ opisu obu tych sposobów postępowania nie wynika wyraźnie, czy gegenote była stałym terenem ograniczonym, czy - zależnie od miejsca zbrodni - zmiennym, gdyż także w tym drugim przypadku byłaby tylko doraźnie ściśle ograniczonym terytorium.

2.4. J. S. Matuszewski widzi $\mathrm{w}$ daninie opolnej bos et vacca opłate za pasanie bydła $w$ lasach książęcych ${ }^{42}$. Wiadomo, że tak się tłumaczy narzaz,

${ }^{35}$ NZPP, s. 168.

${ }^{36}$ NZPP, s. 170.

$37 \mathrm{SUb}$ III, 231 oraz 76.

38 NZPP, s. 170; PiM I, s. 304 i n.

39 Por. PiM I, s. 304 i n.

40 NZPP, s. 170, 172.

${ }^{41} \mathrm{KDS}$ III, 112, r. 1225.

42 J. S. Matuszewski, Vicinia..., s. 159 i n. 
nazywany w Cechach pascuale porcorum ${ }^{43}$. Odpowiada to polskiemu narzazowi, o którym dokument z 1291 r. pisze wyraźnie: ...naraz quod aper dicitur, a kilka wierszy dalej: ... a vicinia quod opole wlgariter nuncupatur, a vacca videlicet et bove. Zaznaczam, że źródło to podkreśla, iź $\mathrm{w}$ przeciwieństwie do starego zwyczaju chce być ścistym przy wyliczeniu podatiów i służebności, których książę się zrzeka na korzyść klasztoru lądzkiego ${ }^{44}$.

W innym dokumencie z 1293 r. książę, nadając wsi szlacheckiej prawo niemieckie, zwalnia ją $\mathrm{m}$. in. a porco, quod naraz dicitur, i znowu kilka wierszy dalej: a vacca et bove, quod opole wlgariter nominatur ${ }^{45}$. Zdarza sie także, że do narzazu zaliczane bywa także świadczenie bos et vacca, ale dokumenty te albo są falsyfikatem, albo pochodzą z 14 . w. Tylko niektóre $z$ nich wystawiono w 13. w. Zwykle jednak w dokumentach wspominajacych o opolu narzaz wymienia się bliżej początku klauzuli libertacyjnej, a bos et vacca osobno, ku końcowi. Przeczy to tłumaczeniu wolu $i$ krowy jako dalszego pascuale.

Jakim sposobem ta danina, bos et vacca, byla splacana przez chlopów? Wymieniony wyżej dokument z $1291 \mathrm{r}$. powiada, że pewne wsie klasztorne debere secum ( $=\mathrm{z}$ ich opolami) stare in contributione opole, videlicet vacca et bove ${ }^{46}$. W dokumencie z 1363 r. (!) czytamy o pewnej wsi, że nie ma ona cum eo ( $z$ opolem) vaccam solvere et bovem ${ }^{47}$. Wól i krowa kosztowaly wtedy około 270 denaró $w^{48}$. Zatem $w$ ramach opola na dwór chlopski przypadała kwota około jednego denara, lub nieco mniej albo więcej.

Istotne jest tu jednak przede wszystkim to, że bos et vacca - wedlug dokumentu z 1277 r. -- byly oplacane przez wicynie krzywińska, a ta wtedy już była stałym terytorium administracyjnym, jak i inne wicynie ówczesnej południowo-zachodniej Wielkopolski, wymienione w dokumencie lubinskim (rzekomo z 1242 r, w rzeczywistości późniejszy falsyfikat): Premut, Costan, Srem, Nedesim, Crivin, Starigrod ${ }^{49}$. Danina ta byla rozprzestrzeniona glownio na zachodzie, to jest $w$ Wielkopolsce, gdzie wtedy powstawaly opola podobne do mających stałe granice śląskich weichbildów.

2.5. Choć z twierdzeniem tym można polemizować - jak czyni to I. S. Matuszewski - historycy określali jako daninę opolną także czynsz miodowy

${ }^{43}$ CDB I, 400, r. 1115 (falsyfikat z 13. w.).

${ }^{44} \mathrm{KDW}$ II, 52 (dokument podejrzany, chyba nieshusznie, w KDP 1 138). Yor. 3. Ma. tuszewski, Immunitet ekonomiczny $w$ dobrach kościola $w$ Polsce do $r$. 1381. Pomari 1936, s. 360 , przyp. 9 .

${ }^{45}$ UDK, s. 362 i n.

${ }^{46}$ KDW II, 51 i n., r. 1291.

${ }^{47} \mathrm{KDW}$ III, 231, B. Kürbis w MPH, ns VIII, s. 180, thumaczy mylnie Wisnensis jako Wisnieviensis.

${ }^{48}$ Por. ówczesne ceny - PiM II, s. 431.

${ }^{49} \mathrm{KDW}$ I, 410, r. 1277; KDW I, 199, r. 1242 (późniejszy falsyfikat). 
znany z 3 wzmianek źródłowych: ab urna mellis provincialis zebranych w podziwu godnej kolekcji $\mathrm{Z}$. Podwińskiej ${ }^{50}$. Mimo że odnalazłem jeszcze jedną wzmiankę o takiej daninie ${ }^{51}$, to nadal pozostaje wątpliwe, co oznaczać ma wyraz provincialis, choć najpewniej moglo tu chodzić jedynie o niewielkie terytorium.

2.6. Należy tu jednak uwzględnić także dwie daisze, pochodzące $z 1270$ i 1271 r., wzmianki. W dokumencie pierwszym książ Bolesław Pobożny zwalnia wieś szlachecką od różnych danin prawa polskiego. Nie ma ona $\mathrm{m}$. in. placić z opolem, co opole placi, czynszu miodu nie oddawać trybunowi wraz $z$ opolem. W drugim dokumencie tego samego whadcy stwierdzono książęcą darowiznẹ w ręce rycerskie usytuowanej pod Gnieznem wsi. $Z$ nadaniem tym zwiazany jest - co prawda chyba interpolowany - immunitet: ...ab opole, a strosza et a castri cittacione, a melle tribuni (tak w kopii drugiej, gdy w pierwszej czytamy melle tributi) ${ }^{52}$. Trybun był polskim wojskim, który w znanej liście urzędów u Kadłubka wystepuje w liczbie mnogiej jako tribuni collegiati, ponieważ najwidoczniej w kasztelanii znajdowało się kilku irybunów. Nazywano ich także sędziami (iudex lub subiudex ${ }^{53}$ ) kompetentnymi dla pewnej części kasztelanii ${ }^{54}$. Czy otrzymywali oni daninę miodową właśnie od takiego malego terytorium albo dystryktu, podobnego do ówczesnych weichbildów?

3. Metamorfoza trybu życia $w$ wyniku zamiany prawa polskiego na niemieckie dosięgnęła najpierw zachodniej Polski, przede wszystkim Siąska, skad zaczęla się rozprzestrzeniać na południową rubież Wielkopolski. Na Dolnym Śląsku doszlo przy tym rychło do przeistoczenia kasztelanii $w$ mniejsze dystrykty, konstytuujące się wokól miast albo rynków na prawie niemieckim ${ }^{55}$ Nazywano je Weichbild (termin złożony ze slów vicus oraz bill, tj. prawo) ${ }^{56}$ Nowe prawo niemieckie obowiązywało odtąd nie tylko w lokacjach miejskich, lecz także we wsiach całego okręgu-dystryktu. Podobna zmiana nastąpiła na Pomorzu, a już od polowy 13. w. zaznaczyla się $w$ poludniowej Wiel-

so Z. Podwińska, Zmiany..., s. 289 i 291.

${ }^{51}$ UDK, s. 368 , r. 1398.

52 KDW VI, 22, r. 1270 oraz 24 , r. 1271.

53 PiM I, s. 299 i n.

${ }^{54}$ Por. O. Kos smann, "Das mittelalterliche Polen Oskar Kossmann's" in der Sicht von K. Modzelewski, ZfO 1989, s. 291.

${ }^{55} \mathrm{H}$. von L a $\mathrm{sch}$, Die schlesische Weichbildverfassung der Kolonisationszeit, [w:] t e $\mathrm{n} \dot{\mathrm{z}} \mathrm{e}$, Beiträge zur schlesichen Rechts- und Verfassungsgeschichte, Konstanz-Stuttgart 1964, s. 83-98, 139; J. J. M enze1, Stadt und Land in der schlesischen Weichbildverfassung, [w:] Die mittelalterlische Städtebildung in südöstliche Europa, hg. v. H. Stoob, Köln-Wien 1977, s. 19-38; W. K u h n, Die Stadtdörfer der mittelalterlichen Ostsiedlung, ZrO 1971, Bd. 20, s. 12-17.

${ }^{56}$ Boguphali II episcopi Posnaniensis chronicon Poloniae. MPH II 480; vicus enim in slavonico proprie civitats dicitur, in qua forum exercetur. Nunquam aliqui dicunt "transeamus ad civitatem" sed "vadamus ad wyk". 
kopolsce, sąsiadującej ze Śląskiem. Terytoria wiejskie wokół nowo założonych miast lub dawnych centrów występują jako ich vicinia lub opole. J. S. Matuszewski konstatuje nawet identyczność z kasztelanią tych zwanych opolem tworów ${ }^{57}$. W rzeczywistości były to raczej części dawnych kasztelanii. Tu chyba należy przypomnieć sformulowanie, kilkakrotnie powtarzane w przywilejach klarysek z Zawichostu, strosa duarum provinciarum, quod opole wlgariter appelatur ${ }^{58}$. Przywileje te co prawda okazaly się falsyfikatami $\mathrm{z}$ początku 14. w., prawdopodobnie jednak fałszerze jeszcze się dobrze orientowali, co należy rozumieć pod opolem tego czasu: prowincję o stalych granicach!

Podobnie w dokumencie z 1263 r. czytamy districtus opole de Mstow ${ }^{59}$, a akt z $1253 \mathrm{r}$. juz wylicze. ówczesne terytoria administracyjne w następujący sposób: ...de quacunque castellania, districtu, civitate, villa vel loco ${ }^{60}$, co wszystko razem pasuje doskonalo do opola nowego typu.

Nawet sam Poznań w $1298 \%$, kledy praxo niemieckie osiągnęło szczyt swego rozwoju w Wielkopolsce, zamienil sie w centrum weichbildu Also verre als der stat wichbilde umfehet, ubir das alles vorle wir gewalt czu richten $[. .$.$] dem vorgenenten voyte { }^{61}$

W 1306 r. Wielkopolska została opanowana na kilka lat przez książąt głogowskich. Henryk II, heres regni Poloniae, dux Slesie, dominus Glogovie et Poznanie, stworzyl w 1310 r. odpowiadający temu rozwojowi nowy dystrykt dookoła miasta Poniec ${ }^{62}$. Kilka tygodni później ten sam książę zakłada dystrykt Góra. Miasteczko to odtąd ma być rynkiem i miejscem sądu dla mieszkańców calego dystryktu ${ }^{63}$. W ten sposób powstawały weichbildy, tj. terytoria prawa miejskiego, obowiązującego niezależnie od przynależności stanowej wszystkich mieszkańców.

W 1312 r. książęcy bracia głogowscy dzielą między sobą Wielkopolskę i Dolny Śląsk, składające się już nie z rozległych kasztelanii, lecz z dystryktów, z których 26 przypada na Wielkopolskę ${ }^{64}$, a między nimi Lubin cum suo districtu [...] Poniec cum suo districtu [...] Góra cum suo districtu [...], do tego znane nam już jako wicynie Premut (Przemęt), Costan (Kościan), Srzem (Śrem), Criwin (Krzywiń), wszystkie cum suo districtu...65. „Opola”

57 J. S. Matuszewski, Vicinia..., s. 223.

$58 \mathrm{KDM} \mathrm{I}, 53$, r. $1257 ; 71$, r. $1262 ; 75$, r. 1262.

59 KDM I, 49.

60 KDM II, 89 i $\mathrm{n}$.

61 W. M a ise 1, Kodeks przywilejów Poznania, „Studia i Materiały do Dziejów Wielkopolski i Pomorza" 1980, 26, s. 160.

62 KDW II, 275.

$63 \mathrm{KDW}$ II, 277, r. 1310.

64 KDW II, 292.

${ }^{65} \mathrm{KDW}$ I, 199. Kościan w dalszym tekście z 1312 r. wymieniony jest jako Costan castrum et civitas cum districtu; Poniec jako civitas, Pobiedziska jako castrum et civitas, Sagan 
te - Giecz, Kostrzyń, Kościan, Przemęt itd. - wymienia J. S. Matuszewski. Jednak według niego nie były to prawdziwe opola, lecz raczej grody kasztelanii ${ }^{6 \sigma}$.

Co $w$ falsyfikacie lubińskim występuje jako vicinia, w dokumencie z 1312 r. nazwane jst dystryktem. Ten zaś, jeśli należał równocześnie do Sląska, niewątpliwie był prawdziwym weichbildem, następcą dawnej kasztelanii. Natomiast na terenach środkowej Polski, np. ziemi łęczyckiej lub sieradzkiej oraz w prowincjach wschodnich do takiego rozwoju nie doszło. Bowiem w centralnej Polsce ksztaltowało się władztwo Władysława Lokietka, który wkrótce mial objąć swym panowaniem niemal całą Polskę. Wielkopolska natomiast jeszcze dotkliwie przeżywala przebudowę swych starych form administracyjnych, wzbudzającą nawet niepokoje wśród miejscowej szlachty.

4. Zachodniosłowiańskie dwory książęce, opierając się na napływającej szlachcie niemieckiej, stały się centrami promieniowania niemieckości, która wnet zaczynała przenikać do Polski, gdzie natrafiło to jednak na reakcje szlachty polskiej. Na Kujawach, gdzie książę począł się otaczać niemieckim rycerstwem, już w 1268 r. doszło do rewolty miejscowej elity. Władca musial ostatecznie zrezygnować z niemieckich rycerzy, ale w dalszym ciągu mógł sprowadzać i osiedlać niemieckich chłopów i mieszczan ${ }^{67}$. Szlachta widocznie obawiała się tylko Niemców-rycerzy na dworze książęcym, nie ludzi niższych stanów. Natomiast w międzyczasie w Wielkopolsce postawa szlachty nawet wobec mieszczan i chlopów uległa zdecydowanemu pogorszeniu, gdy pod panowaniem książąt glogowskich stany te uzyskały lepszą pozycje prawną $w$ ramach opoli i prawa niemieckiego.

W ogóle Polska popadła w tym czasie w konflikty ze swoimi niemieckimi sąsiadami. Na północy narastał spór z Krzyżakami. Na zachodzie zaś margrabiowie brandenburscy naruszali dawne pogranicze. Książęta śląscy i pomorscy, otoczeni niemieckim dworem, zagrażali z północy i poludnia rubieżom Wielkopolski. Na Śląsku, w Wielkopolsce i Małopolsce miasta przemieniały się $w$ potężne centra polityczne. Nietrudno sobie zatem i dziś wyobrazić, że generalnie stosunek Polaków wzglẹdem niemieckich sąsiadów zaczął się zdecydowanie pogarszać.

Zrządzeniem losu było, że w tym samym czasie wymieraly niektóre linie Piastów i zacząl się proces ponownego lączenia polskich prowincji i księstw. $\mathrm{Na}$ czoło tej akcji wnet wybil się Władysław Lokietek, któremu w $1296 \mathrm{r}$. poddała się nawet Wielkopolska. Jego niezbyt giętkie, wręcz jednostronne

i Niemysłów jako civitas et castrum. W sprawie lubińskich falsyfikatów por. Z. P e r zan ow sk i, Dokumenty opactwa Benedyktynów w Lubiniu =KDW ns, z. 1, Warszawa-Poznań 1975.

66 J. S. M at us zewski, Vicinia..., s. 214.

${ }^{67}$ O. Kossma n n, Rügen im hohen Mittelalter, ZfO 1983, Bd. 52, s. 196. 
postępowanie wywoływało narastający opór, o którym świadczy, zdaje się następujący dwuwiersz w Roczniku kapituły poznańskiej:

Anno millesimo trecentesimo minus uno

deflet Theutonicos Poznania passa secundos ${ }^{68}$.

Lokietek musiał zbiec z kraju, nawet ze swych ziem dziedzicznych, i ukryć się na Węgrzech.

Tymczasem Wielkopolska opanowana została przez książąt glogowskich, o czym była już mowa powyżej. O nich tenże Rocznik kapitulny pisze: ...hos, quia iuvenes erant et tenelli [...] alligaverunt consiliis Theutonici, ita quod nihil poterant facere, nisi quod placeret Theutonicis [...] et dederunt eis consilium, ut totam Polonicam exterminarent, tam ecclesiasticas personas quam seculares milites. $\mathrm{Na}$ marginesie tegoz Rocznika Theotonici [...] volentes linguam Polonicam anichilare ${ }^{69}$. Zniemczenie ówczesne na Sląsku i Pomorzu było sygnałem ostrzegawczym dla polskiej szlachty, która mniej więcej od $1300 \mathrm{r}$. nagle powstrzymala się od dalszej kolonizacji na prawie niemieckim (przedstawia to rys. 1). Odiąd ta kolonizacja, stopniowo podejmowana na nowo w dorzeczu Wisly i Warty, ograniczała się do polskiego elementu chłopskiego.

W tym czasie Łokietek zdążył opanować Małopolskę. Krakowiacy jednak zapaleni - według Rocznika kapitulnego - gniewem i furiq niemiecka, odmówili władcy posłuszeństwa. Ich wójt, Albert, zwrócił się o pomoc do księcia Bolka opolskiego, który jednak niebawem z Lokietkiem się porozumiał i z Krakowa ustąpił. Wówczas, w 1312 r., doszło do krwawej zemsty. Mieszczańscy przywódcy byli włóczeni końmi, a ich szczątki wisiały na szubienicy, aż się rozleciały ${ }^{70}$. Szczytem tego przewrotu narodowego były wybuchające wojny $\mathrm{z}$ zakonem krzyżackim. Ostatecznie miasta w Polsce silnie ucierpiały i utraciły swoją rangę. Prawo miejskie wyblakło. Powstające luki gospodarcze wypełniane były przez mieszczan żydowskich.

Lokietek wróciwszy w 1314 r. do Wielkopolski, wstrzymywał wywolane przez Ślązaków zmiany administracyjne. Rozwój wicynii wokól miejskich centrów został przerwany. Stany mieszczański i chłopski zostały ponownie odsunięte na drugorzędny plan. Organizacja sądowa staje się niejasną.

Przez jakiś czas urzędujące sądy „wędrowne” przedstawiały się jeszcze jako iudicia regalia, które odbywały się - prócz pewnych centralnych miast - raz tu, raz tam, w imieniu króla dla wszystkich stanów, pod kierownictwem

${ }^{68}$ MPH ns, VI, s. 53; W roku tysięcznym trzechsetnym mniej jeden/Płacze Poznań po Niemcach cierpiąc od [ich] następców.

69 Ibidem, s. 55. Zatem Niemcy udzielali takich rad młodym książętom, że nie mogli nic innego czynić, niż co sie Niemcom podobalo [...] i dali im [książętom] rade, wygubić caly naród polski zarówno osoby duchowne, jak i swieckich rycerzy.

${ }^{70}$ MPH II, 815, r. 1312. Rezygnuje z opisu podobnych wydarzeń w miastach wielkopolskich, w Gdańsku, Lwowie itd. 


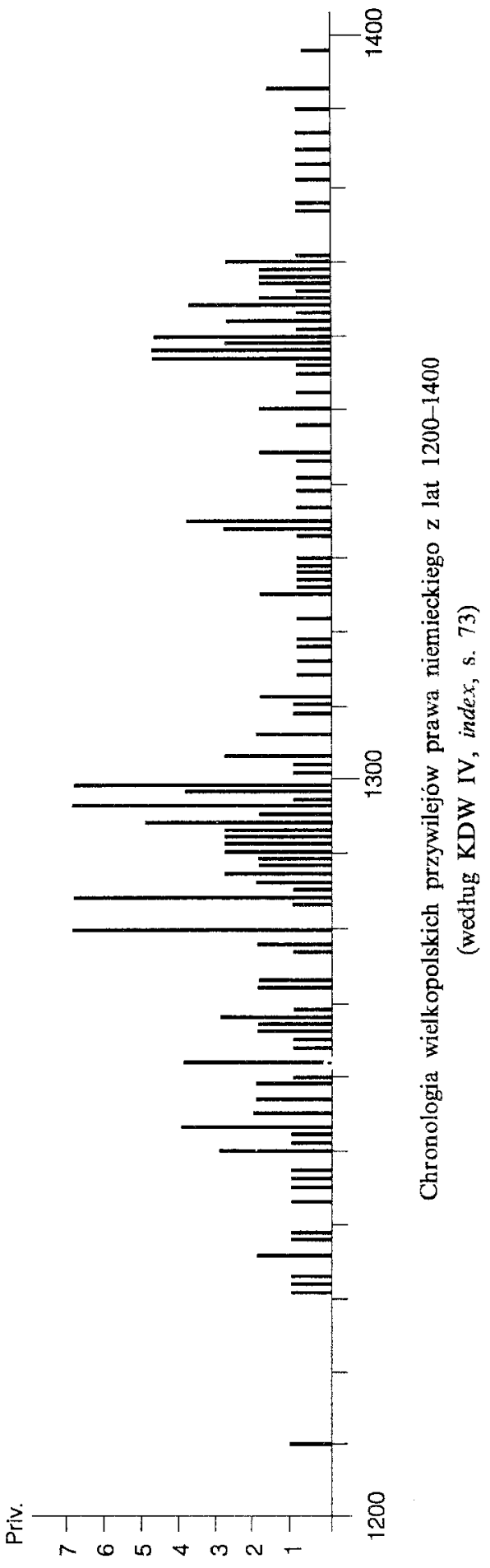


starostów ziem lub ich zastępców. Lecz władza królewska topniała już w stuleciach 14. i 15., a szlachta zdobywała coraz większe wpływy również w zakresie sądownictwa. W końcu sądy uwolnione od zwierzchnictwa starostów odbywaly się odtąd pod nazwą iudicium terrestre ${ }^{71}$. Mieszczanie i chłopi zostali w końcu spod tego sądownictwa wyłączeni, w przeciwieństwie do dawnych opoli, w których funkcjonowaniu braìy udział wszystkie stany. Szlachta była - można powiedzieć - kawalerią, konnym rycerstwem. Ograniczenie właściwości sądu do stanu szlacheckiego doprowadziło do rozszerzenia okręgów sądowych: śląskie weichbildy i wielkopolskie dystrykty ery dolnośląskiej były o połowę mniejsze. Przywileje koszyckie z 1374 r. wyliczają dla Wielkopolski już tylko następujące castra et civitates [...] de quibus honores et sedes iudiciales procedunt: Poznania, Medzerecz, Izbansyn, Kalis, Nakel, Kostyn et Pizdri ${ }^{2}$. Natomiast dystryktów ery glogowskiej w Wielkopolsce - jak wskazaliśmy - było 26. Mapa Wielkopolski Gąsiorowskiego, przedstawiająca stan administracyjny z końca 16. w., wykazuje już tylko 10 powiatów: Wałcz, Nakło, Kcynię, Gniezno, Poznan, Pyzdry, Konin, Kościan, Wschowę, Kalisz, przy czym Wałcz tutaj móglby być nawet opuszczony ${ }^{73}$. Liczba powiatów była zatem trzykrotnie mniejsza od liczby dystryktów opolnych z $1312 \mathrm{r}$.

Niestety nie znamy ówczesnych rozporządzeń o wprowadzaniu nowych podziałów administracyjnych albo sądowych. Według S. Kutrzeby, którego zdanie podtrzymuje A. Gąsiorowski, to wszystko wyroslo i rozwinęlo sie powoli: w przeciągu 14. stulecia wytworzyła siç niepostrzeżenie zasada pozywania mieszkańców pewnych okręgów do utworzonego tymczasem sądu. Okręgi te nazywano powiatami ${ }^{74}$. Nazwa przetrwala do dnia dzisiejszego.

A. Gąsiorowski wywodzi ten termin od, ,wiat", co oznaczać ma 'mówić' - w czym idzie za A. Brücknerem, slawnym filologiem-slawistą ${ }^{75}$, przy czym zaznacza, że inne języki slowiańskie tego terminu nie znają. W słowniku rosyjsko-niemieckim J. Pawłowskiego jest on co prawda wymieniony, ale ograniczony do zachodniej Rosji ${ }^{76}$. Tamże znajdujemy czasownik powjestiti i rzeczownik vjestj. W dokumencie z 1357 r. natrafiłem na słowo „powieścić”: król Kazimierz III rozkazuje m. in. ipsum (pewnego dziedzica) citari wlgariter

${ }^{71}$ A. Gąs i orowski, Powiat w Wielkopolsce XIV-XVI w., Poznań 1965, s. 15.

72 Ibidem, s. 64.

73 lbidem, mapa.

${ }^{74} \mathrm{Za}:$ A. Gąs siorowski, Powiat..., s. 16 i n.

75 Ibidem, s. 20; A. B r ü ck ne r, Slownik etymologiczny jezyka polskiego, Warszawa 1957 , s. 614. R. Trautma n n, Baltischslavisches Wörterbuch, Göttingen 1923, s. 339, ma: „slvk. 'vetit', mówic'". W staroruskiej kronice Nestora (MPH I, 644), "vjestnik' thumaczono na język polski przez 'zwiastun'. W kronice Th ie tma ra (V 6, VI 37, VII 15) mowa o wjetnikach ('vethenici') na podgrodziu zamku miśnieńskiego koło $1000 \mathrm{r}$.

76 J. Pawlowsky, Russisch-deutsches Wörterbuch, Ryga-Lipsk 1900, s. 1080. 
pouczczicz ${ }^{77}$, tj. wezwać, pozwać, oznajmiać, w lacińskich dokumentach często wyrażone przez evocare. Jeszcze w dawnej Kongresówce taki pozew nazywal się powiastką. W nowo wydanej przez T. Jurka księdze sądowej kaliskiej mówi się o powiastce tego rodzaju słowami vulgariter powestczi, za pomocą której wójt pyzdrski wzywał do sądu i podawał termin ${ }^{78}$. Słowo „powiat" widocznie oznaczało pozwane gremium. Udział opola wygasł ostatecznie. Tylko pozwany mial się stawić, a "powieszczano" zasadniczo Polaków prawie wyłącznie stanu szlacheckiego. Powiat okazal się antytezą opola. Mieszczan i chlopów pozbawiono ich praw.

Znany powszechnie awans ówczesnej szlachty polskiej oraz utrwalenie się powiatu były $w$ znacznej mierze skutkiem oporu szlachty przeciw zaletom opola wobec niższych stanów społecznych. Chłopi, którzy w 14 . w. w Polsce zachodniej zdobyli spoleczny awans na polskim lub niemieckim prawie, dwa stulecia później byli już chłopami pańszczyźnianymi. Ten upadek niższych stanów, „sukces szlachty”, przyczynil się niewątpliwie do zmierzchu państwa polskiego w 18. stuleciu. Korzenie tego upadku sięgaja więc wstecz aż do 14. w. Tylko karykatura opola pojawiała się jeszcze okazjonalnie $w$ służbie szlachty $w$ późniejszych stuleciach przy regulacji granic $^{79}$.

77 ZDM IV, 103.

78 Ksiega ziemska kaliska 1400-1409, wyd. T. Jurek, Poznań 1991, s. 47.

79 $\mathrm{O}$ tej końcowej fazie staropolskiego opola kilka danych $\mathrm{w}$ rozprawie $\mathrm{K}$. Buczka, Organizacja opolna..., s. 243-248. 